Proceedings

\title{
Detection and Monitoring of Alien Plant-Sucking Insect Spe- cies on the Black Sea Coast of Russia ${ }^{\dagger}$
}

\author{
Natalia Karpun ${ }^{1,2}$, Elena Zhuravleva ${ }^{1}$, Boris Borisov ${ }^{3}$, Natalia Kirichenko ${ }^{4,2}$, Dmitry Musolin ${ }^{2}$ \\ 1 Federal Research Centre the Subtropical Scientific Centre of the Russian Academy of Sciences, Sochi, Russia; \\ nkolem@mail.ru; zhuravleva.cvet@mail.ru \\ 2 Saint Petersburg State Forest Technical University, Saint Petersburg, Russia; musolin@gmail.com \\ 3 AgroBioTechnology LLC (Production and Research Company), Moscow, Russia; borborisov@mail.ru \\ 4 Sukachev Institute of Forest, Siberian Branch of the Russian Academy of Sciences, Federal Research Center \\ «Krasnoyarsk Science Center SB RAS», Krasnoyarsk, Russia; nkirichenko@yahoo.com \\ * Correspondence: nkolem@mail.ru \\ + Presented at the 1st International Electronic Conference on Entomology (IECE 2021), 1-15 July 2021; \\ Available online: https://iece.sciforum.net/.
}

Citation: Karpun N.; Zhuravleva E.; Borisov B.; Kirichenko N.; Musolin D. Detection and Monitoring of Alien Plant-Sucking Insect Species on the Black Sea Coast of Russia, in Proceedings of the 1st International Electronic Conference on Entomology, 1-15 July 2021, MDPI: Basel, Switzerland, doi:10.3390/IECE-10489

Published: 30 June 2021

Publisher's Note: MDPI stays neutral with regard to jurisdictional claims in published maps and institutional affiliations.

Copyright: () 2021 by the authors. Submitted for possible open access publication under the terms and conditions of the Creative Commons Attribution (CC BY) license (http://creativecommons.org/licenses /by/4.0/).

\begin{abstract}
The Black Sea coast of Russia is a recipient region for many alien insect pests. In 2018, we detected an invasive woolly whitefly Aleurothrixus floccosus (Maskell) (Homoptera: Aleyrodidae) attacking citruses in the agrocenoses and ornamental plantations in the region of Sochi. Furthermore, we clarified the secondary range of an alien whitefly, Aleuroclava aucubae (Kuwana) (Homoptera: Aleyrodidae) in the humid subtropics of Russia. Another plant-sucking invader, the western conifer seed bug Leptoglossus occidentalis Heidemann (Heteroptera: Coreidae) was revealed in the Black Sea coast of Crimea in 2019. Further distribution and trophic associations of these novel alien pests are discussed.
\end{abstract}

Keywords: invasive species, pest, whitefly, western conifer seed bug, Russia, Black Sea coast

\section{Introduction}

The invasions of alien species are recognized as a global threat [1,2]. Indeed, the invasive organisms can considerably impact biodiversity, ecosystem functioning and economy of invaded regions [3-7]. Nowadays, more and more alien species became known as serious pests in agriculture and forestry in different countries around the world [8], including Russia [9].

The Black Sea coast of Russia, with its mild climate, is one of the main recipient regions of invasive alien insect species in the country. The first documentation of alien phytophagous insects refers to the end of the XIX century that, in fact, coincided with the period of active introduction of fruit and ornamental subtropical plants [10]. Since the end of the XX century, the number of alien organisms intercepted in the region has notably increased. The active development of infrastructure and the intense landscaping of the Sochi coast (for what many plants for planting were imported to the region from European nurseries) as well as increased interregional traffic altogether led to the invasion of at least 35 alien phytophagous species that were intercepted here in 2000-2018 [11-15]. Many of them have effectively established in the region and are presently expanding their ranges. The two moths (Cydalima perspectalis (Walker) (Lepidoptera: Crambidae) and Paysandisia archon (Burmeister) (Lepidoptera: Castniidae)), the brown marmorated stink bug Halyomorpha halys (Stål) (Heteroptera: Pentatomidae) and two coleopteran species (Rhynchophorus ferrugineus (Olivier) (Coleoptera: Curculionidae) and Lamprodila festiva L. (Coleoptera: Buprestidae)) have already caused enormous damage to the local ecosystems. 
The aim of our study was the early detection of novel alien insect pests, the monitoring of the invaders that have already established their populations, and determination of their trophic associations on the Black Sea coast of Russia.

\section{Materials and Methods}

The detection of alien herbivorous insects was carried out in the plantations on the Black Sea coast of Russia (Republic of Crimea, Sochi, Tuapse, Gelendzhik, Anapa) in 20192020 in a frame of phytosanitary monitoring program. We run surveys in multiple transects in the mentioned above settlements during the entire vegetation season. We were focused on plantations in sanatorium and resort areas, municipal parks, gardens, street plantings. We also run surveys in agrocenoses (in particular, subtropical fruit crops), in a less extent, in natural ecosystems. Insects found at different life stages were collected and fixed following classical techniques [16] for further morphological identification. The fragments of plant organs damaged by alien species were collected and placed in annotated herbarium. The identification of whiteflies was confirmed by the specialist at Zoological Institute of the Russian Academy of Sciences (Saint Petersburg). All specimens are stored at the collection of Subtropical Scientific Centre of the Russian Academy of Sciences (Sochi).

\section{Results and Discussion}

\subsection{Detecting of woolly whitefly Aleurothrixus floccosus}

Regular surveys of citrus plantations in Sochi allowed us to spot peculiar symptoms on the underside of satsuma mandarine, lemon, and orange leaves. On the leaves, a felt, waxy white coating was present, under which larvae and pseudopupae of an alien species were found. In contrast to that, the citrus whitefly Dialeurodes citri (Ashmead) (Homoptera: Aleyrodidae), known in the region for ages, does not produce wax threads. The discovered species was identified as woolly whitefly Aleurothrixus floccosus (Maskell) (Homoptera: Aleyrodidae) (Figure 1).
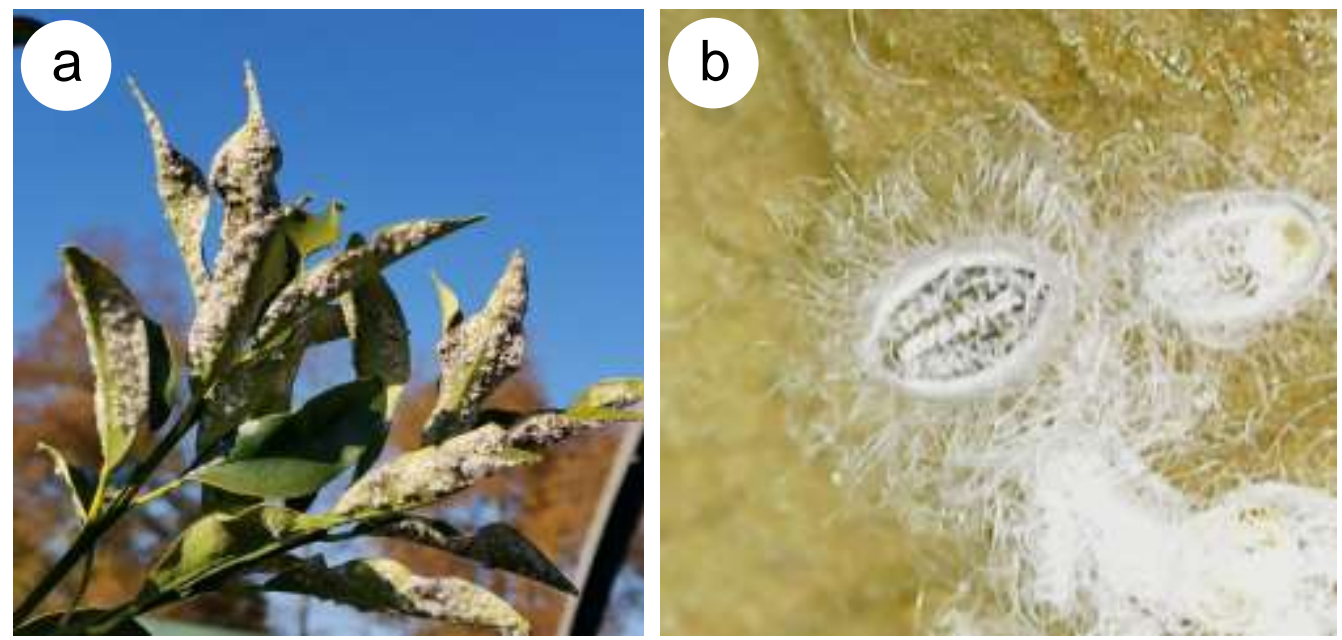

Figure 1. The colony of Aleurothrixus floccosus (Maskell) (Homoptera: Aleyrodidae) on satsuma mandarine leaves: the general view to the colony (a); pseudopupae (approximate length $1.0 \mathrm{~mm}$ ) (b). Sochi, 2020. Photos taken by N. Karpun.

Aleurothrixus floccosus probably originates from South America [17]. The pest has invaded the USA, Africa, the Middle East, East and Southeast Asia [17]. In the early 1970s, it was reported from Spain and southern France, later on recorded in Morocco, Portugal, 
Italy, Malta, Greece, and Montenegro [17-20]. Since 1994, the species was eventually detected in Turkey, in the provinces on the Mediterranean and Aegean coasts [21]. So far, it has not been found in Australasia [22].

The colonies of $A$. floccosus were recorded in Russia in 2018 on lemon and satsuma mandarine trees in the two districts of Sochi (Central and Khosta districts). Obviously, the pest had arrived to the region some years before its first documentation in 2018, as already in 2019, it was abundant throughout the entire territory of the humid subtropics of Russia. The pest prefers leaves on younger shoots. We observed massive colonies of A. floccosus on fresh shoots starting from the end of August (Figure 1a).

Together with the colleagues from the Institute of Agriculture of the Academy of Sciences of Abkhazia we showed that $A$. floccosus prefers lemon trees followed by satsuma mandarine, orange, grapefruit, and kumquat [23]. We noted that the density increase in A. floccosus populations results in the density decrease of $D$. citri suggesting interspecific competition between these two species sharing the same host plants.

\subsection{Distribution of Aleuroclava aucubae in subtropical zone of Russia}

Another alien whitefly species Aleuroclava aucubae (Kuwana) (Figure 2a), having East Asian origin (Japan, China, and Korea), was discovered in the southern Russia (Agura gorge, Sochi National Park) in 2019 [24]. In 2020, we continued monitoring the distribution and exploring trophic relations of this species.
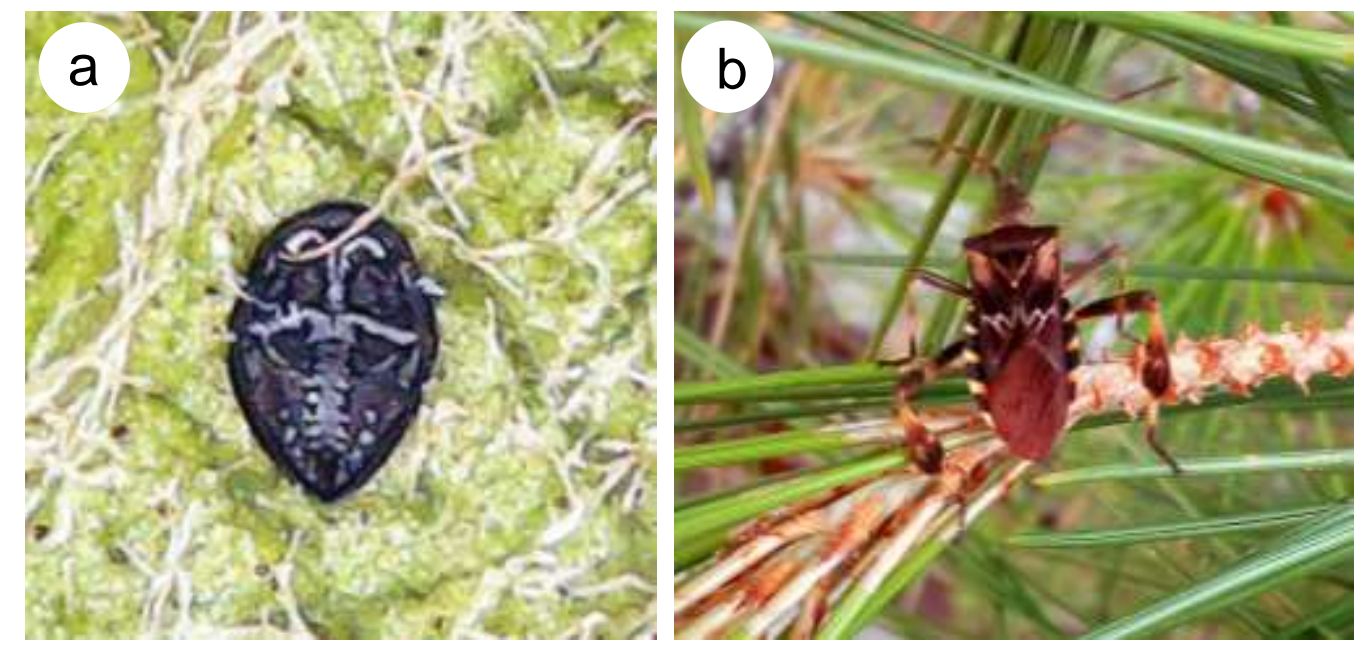

Figure 2. Pseudopupa of Aleuroclava aucubae (Kuwana) (Homoptera: Aleyrodidae) (approximate length $0.7 \mathrm{~mm}$ ) on a leaf of the loquat (Eriobotrya japonica (Thunb.) Lindl.) in Sochi, 2020 (a). Adult of Leptoglossus occidentalis Heidemann (Heteroptera: Coreidae) on Pinus brutia var. pityusa (Steven) Silba, in village Partenit (southern Crimea), 2019. Photos taken by B. Borisov (a), E. Zhuravleva (b).

Aleuroclava aucubae was found in 2020 in several districts of the Sochi region: Central district (in urban and roadside plantings), Khosta (in the Sochi arboretum, ornamental plantings and orchards), Adler («Gluboky Yar» gorge in valley of the Mzymta River), and Lazarevsky district (Svirskoye gorge and roadside plantings).

Initially, pseudopupae of A. aucubae were observed only on the leaves of Ficus carica L. and Ulmus glabra Huds., whereas a year later, the insect was already found on 31 plant species from 15 families across many districts of the Sochi region. About half of the host plants (15 species) are native to the Black Sea cost. Among them, for example, Ligustrum vulgare L., Crataegus microphylla K. Koch., Sambucus ebulus L., Prunus laurocerasus L., Hedera colchica (K. Koch) K. Koch. For the first time, A. aucubae was recorded on Acer campestre L. and Acer pseudoplatanus L., although plant species from Sapindaceae family have not previously been known as hosts of this insect. Despite A. aucubae was found on many plants, the level of its impact remained insignificant, at least before 2020 inclusive. 


\title{
3.3. Distribution of western conifer seed bug Leptoglossus occidentalis in Crimea
}

The western conifer seed bug Leptoglossus occidentalis Heidemann (Figure 2b), originally known from North America, was for the first time recorded in Russia in 2010-2011 [25]. Over the past 10 years, it has distributed across large part of the Black Sea coast (Krasnodar Territory, the Republic of Abkhazia) and penetrated into adjacent regions (Rostov Region, the Republic of Adygea, Stavropol Territory, the North and South Ossetia) [2527]. In Republic of Crimea, it was discovered in 2010-2011 in Simferopol [25], where, by 2014, it was already highly abundant [28]. In 2019-2020, we documented the bug, already as a regular species, on Pinus pinea, P. brutia var. pityusa (Steven) Silba in the villages Simeiz, Gurzuf, and Partenit (southern coast of Crimea) and on Pinus pallasiana D. Don, $P$. sylvestris L., and P. brutia var. pityusa in the vicinity of Sevastopol. Bearing in mind that Nikitsky Botanical Garden (one of the oldest botanical gardens in Europe) and other dendrological parks where wide range of trees from Pinaceae and Cupressaceae families grow are located on the southern coast of Crimea, the spectrum of potential host plants of the pest in the region has yet to be clarified.

\section{Conclusions}

Summing up, the Black Sea coast of Russia serves some kind of gateway through which many alien phytophagous insect pests regularly enter the country, and from where their secondary ranges begin towards adjacent territories. Here we reported about recent detection of three alien sucking insects on the Black Sea coast of Russia. Bearing in mind that these newly arrived alien species can negatively affect local ecosystems, further studies of their biology and ecology (including phenology, voltinism, trophic associations, and the potential impact) would be urgently needed.

\begin{abstract}
Author Contributions: Conceptualization, NKar, NKir, DM; methodology, NKar, EZ, BB; validation NKar, EZ, BB; investigation, NKar, EZ, BB; writing the original draft, NKar, EZ, BB, NKir; project administration, DM; funding acquisition, DM. All authors have read and agreed to the published version of the manuscript.
\end{abstract}

Funding: This research was funded by the Russian Science Foundation, project № 21-16-00050, https://rscf.ru/project/21-16-00050/.

Institutional Review Board Statement: Not applicable.

Informed Consent Statement: Not applicable.

Data Availability Statement: Data are available on request from the corresponding author.

Acknowledgments: We thank Dr. Il'ya Gavrilov-Zimin (St. Petersburg) for verification of whiteflies.

Conflicts of Interest: The authors declare no conflict of interest.

\section{References}

1. Price, J., Berney, P., Ryder, D., Whalley, R.D.B., Gross, C. Disturbance governs dominance of an invasive forb in a temporary wetland. Oecologia 2011, 167, 759-769.

2. Elton, C.S. The ecology of invasions by animals and plants. Springer Nature, 2020, $181 \mathrm{p}$.

3. Pimentel, D., McNair S., Janecka J., Wightman J., Simmonds C., O'Connell C., Wong E., Russel L., Zern J., Aquino T., Tsomondo T. Economic and environmental threats of alien plant, animal, and microbe invasions. Agric. Ecosyst. Environ. 2001, 84, 1-20.

4. Elliott, M. Biological pollutants and biological pollution - an increasing cause for concern. Mar. Pollut. Bull. 2003, 46, 275-280.

5. Kovac, K.F., Haight, R.G., McCullough, D.G., Mercader, R.J., Siegert, N.W., Liebhold, A.M. Cost of potential emerald ash borer damage in U.S. communities, 2009-2019. Ecol. Econ. 2010, 69, 569-578.

6. Bradshaw, C.J., Leroy, B., Bellard, C., Roiz, D., Albert, C., Fournier, A., Barbet-Massin, M., Salles, J.M., Simard F., Courchamp F. Massive yet grossly underestimated global costs of invasive insects Nat. Commun. 2016, 7, 1-8.

7. Seebens, H., Blackburn, T.M., Dyer, E.E. et al. The global rise in emerging alien species results from increased accessibility of new source pools. PNAS 2018, 115(10), 1-10.

8. Schaefer, C.W., Panizzi, A.R. (eds.) Heteroptera of Economic Importance. Boca Raton, Florida, U.S.A.: CRC Press, 2000,828 p.

9. Maslyakov, V.Yu., Izhevskiy, S.S. Invasions of Phytophagous Insects into the European Part of Russia. Moscow, 2011, 272 p. (in Russian) 
10. Karpun, N.N. The structure of pests complexes of woody plants in the humid subtropics of Russia and the biological substantiation of protection measures: D. Sc. dissertation. Sochi, 2018, 399 p. (in Russian)

11. Karpun, N.N., Ignatova, Ye.A., Zhuravleva, E.N. New species of harmful entomofauna on ornamental woody plants in humid subtropics of Krasnodar region. Izvestia Sankt-Peterburgskoj Lesotehniceskoj Akademii 2015, 211, 189-203. (in Russian).

12. Karpun, N.N., Zhuravleva, E.N., Volkovitsh, M.G., Protsenko, V.Ye., Musolin, D.L. To the fauna of new alien pest species on woody plants in humid subtropics of Russia. Izvestia Sankt-Peterburgskoj Lesotehniceskoj Akademii 2017, 220, 169-185. (in Russian)

13. Karpun, N.N. Features of formation of dendrophagous invasive pest fauna in the humid subtropics of Russia at the beginning of the XXI century. Izvestia Sankt-Peterburgskoj Lesotehniceskoj Akademii 2019, 228, 104-119. (in Russian)

14. Musolin, D.L., Konjević, A., Karpun, N.N., Protsenko, V.Ye., Ayba, L.Ya., Saulich, A.Kh. Invasive brown marmorated stink bug Halyomorpha halys (Stål) (Heteroptera: Pentatomidae) in Russia, Abkhazia, and Serbia: Range expansion, early stages of establishment and first records of damage to local crops. Arthropod-Plant Inter. 2018, 12, 517-529.

15. Zhuravleva, E.N. The first appearance of the Ohrid leaf miner Cameraria ohridella (Lepidoptera: Gracillariidae) on the horse chestnut in the Greater Sochi, The Kataev Memorial Readings - VIII. Pests and Diseases of Woody Plants in Russia: the abstracts, Saint Petersburg; D.L. Musolin, A.V. Selikhovkin, Eds; Saint Petersburg, Russia, 2014, 32. (in Russian)

16. Golub, B.V., Tsurikov, M.N., Prokin, A.A. Insect Collections: Gathering, Processing and Storage of Material. Moscow, 2012, 339 p. (in Russian)

17. Aleurothrixus floccosus (woolly whitefly). CABI Invasive Species Compendium. Available online: https://www.cabi.org/isc/datasheet/4538. (Accessed: 01 June 2021)

18. Katsouannos, P. First record of Aleurothrixus floccosus (Mask.) (Homoptera: Aleyrodidae) in Greece and some observations on its phenology. Entomol. Hell. 1991, 9, 69-72.

19. Malumphy, C., Radonjić, S., Hrnčić, S., Raičević, M. New data on the whiteflies (Insecta: Hemiptera: Aleyrodidae) of Montenegro, including three species new for the country. Acta Entomol. Serbica 2015, 20, $29-41$.

20. Nakahara, L.M. Notes and exhibitions. Proc. Hawaii. Entomol. Soc. 1983, 24, 185.

21. Ulusoy, M.R., Vatansever, G., Erkılic, L., Uygun, N. Studies on Aleurothrixus floccosus (Maskell) (Homoptera, Aleyrodidae) and its parasitoid, Cales noacki Howard (Hymenoptera, Aphelinidae) in the East Mediterranean Region of Turkey. J. Pest Sci. 2003, $76,163-169$.

22. Mercado, V.T., Fernández, E.S., Giliomee J.H. Life table parameters of the woolly whitefly Aleurothrixus floccosus (Hemiptera: Aleyrodidae) and its parasitoid Cales noacki (Hymenoptera: Aphelinidae) Eur. J. Entomol. 2014, 111, 251-256.

23. Ayba, L.Ya., Karpun, N.N., Kulava, L.D., Shoshina, E.I., Sabekia, D.A. Resistance of citrus crops in Abkhazia to damage by the woolly whitefly Aleurothrixus floccosus (Maskell). IOP Conference Series: Earth and Environmental Science 2021, $723,022057$.

24. Gavrilov-Zimin, I.A., Borisov, B.A. Aleuroclava aucubae (Homoptera: Aleyrodinea), a new adventive species for Russian Black Sea Coast, and its concomitant entomoparasitic fungus Conoideocrella luteorostrata (Ascomycota: Hypocreales: Clavicipitaceae). Zoosyst. Ross. 2020, 29, 3-10.

25. Gapon, D.A. First records of the western conifer seed bug Leptoglossus occidentalis Heid. (Heteroptera, Coreidae) from Russia and Ukraine, regularities in its distribution and possibilities of its range expansion in the Palaearctic region. Entomol. Rev. 2013, 93, 174-181.

26. Gninenko, Yu.I., Gapon, D.A., Stschurov, V.I., Bondarenko, A.S. Western conifer seed bug Leptoglossus occidentalis (Heteroptera, Coreidae) appeared in Russia. Zashchita i Karantin Rastenii (Plant Protection and Quarantine) 2014, 6, 38-40. (in Russian)

27. Gapon, D.A., Busarova, N.V., Komarov, Yu.E. New finds of the western conifer seed bug Leptoglossus occidentalis (Heteroptera: Coreidae) in Russia and adjacent territories. Caucasian Entomol. Bull. 2016, 12, 221-222. (in Russian)

28. Stryukova N.M. Invasive insects in the Republic of Crimea. Actual Directions of Scientific Research of the XXI Century: Theory and Practice 2014, 2, 119-124. (in Russian) 